\title{
Understanding building-occupant-microbiome interactions toward healthy built environments: A review
}

\author{
Shuai $\mathrm{Li}^{1}$, Zhiyao Yang $^{3}$, Da Hu ${ }^{1}$, Liu Cao ${ }^{1}$, Qiang He $\left.(\bowtie)\right)^{1,2}$ \\ 1 Department of Civil and Environmental Engineering, University of Tennessee, Knoxville, TN 37996, USA \\ 2 Institute for a Secure \& Sustainable Environment, University of Tennessee, Knoxville, TN 37996, USA \\ 3 Lyles School of Civil Engineering, Purdue University, West Lafayette, IN 47907, USA
}

\section{H I G H L I G H T S}

- The built environment, occupants, and microbiomes constitute an integrated ecosystem.

- This review summarizes research progress which has focused primarily on microbiomes.

- Critical research needs include studying impacts of occupant behaviors on microbiomes.

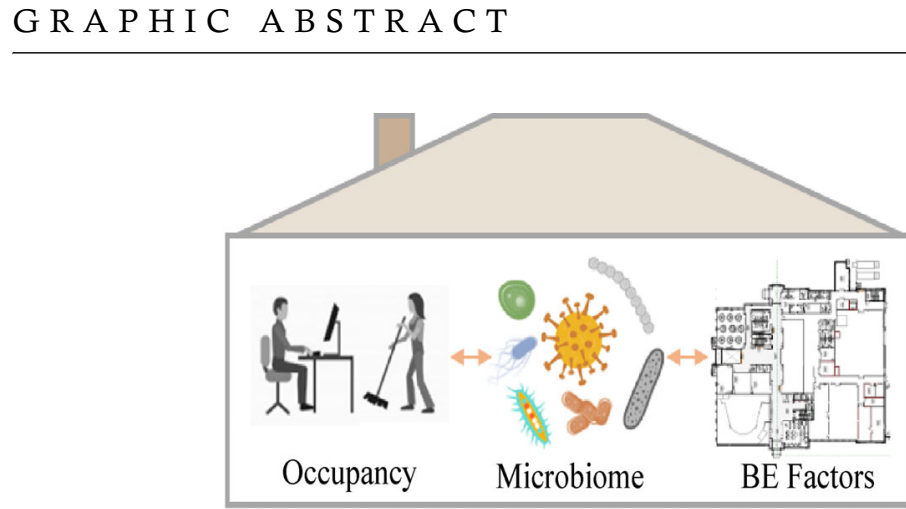

\begin{abstract}
A B S T R A C T
Built environments, occupants, and microbiomes constitute a system of ecosystems with extensive interactions that impact one another. Understanding the interactions between these systems is essential to develop strategies for effective management of the built environment and its inhabitants to enhance public health and well-being. Numerous studies have been conducted to characterize the microbiomes of the built environment. This review summarizes current progress in understanding the interactions between attributes of built environments and occupant behaviors that shape the structure and dynamics of indoor microbial communities. In addition, this review also discusses the challenges and future research needs in the field of microbiomes of the built environment that necessitate research beyond the basic characterization of microbiomes in order to gain an understanding of the causal mechanisms between the built environment, occupants, and microbiomes, which will provide a knowledge base for the development of transformative intervention strategies toward healthy built environments. The pressing need to control the transmission of SARS-CoV-2 in indoor environments highlights the urgency and significance of understanding the complex interactions between the built environment, occupants, and microbiomes, which is the focus of this review.
\end{abstract}

\section{Introduction}

The built environment (BE) harbors diverse microbial populations including viruses, bacteria, fungi, and protozoa (Adams et al., 2016; Gilbert and Stephens, 2018; Dannemiller, 2019), which collectively constitute the microbiomes of the built environment (MoBE). Humans have extensive interactions with the microbiomes that are in the air circulating in buildings, in the water flowing in

$\triangle$ Corresponding author

E-mail: qianghe@utk.edu plumbing systems, and on the surfaces from the most inaccessible to the most touched objects (NASEM, 2017). In developed countries, people spend about $90 \%$ of their time indoor (Klepeis et al., 2001). Increasing urbanization and modernization will likely make people in developing countries spend more time indoors (Popkin, 1999). Thus, the majority of microbiomes encountered by most humans during their lifetime are those present in the BE (Leung and Lee, 2016). There are diverse taxonomic groups in MoBE, which has been revealed by the rapid development and application of culture-independent, high-throughput sequencing techniques. Evidently, it is essentially impossible to characterize MoBE with conventional culture- 
dependent techniques, which are capable of targeting only a small portion of the MoBE that can be cultivated under laboratory conditions. Common bacterial genera in indoor environments include Pseudomonas, Acinetobacter, Staphylococcus, Corynebacterium, Sphingomonas, and Clostridium, while common fungi may be represented by populations associated with Cladosporium, Penicillium, and Aspergillus (Wilkins et al., 2016). The MoBE differs considerably in built environments with different functionalities, such as residential homes, hospitals, schools and daycare centers, transit systems, shopping malls, public restrooms, offices, museums, food processing facilities, fitness centers, aircraft, and even the international space station (Tringe et al., 2008; Kembel et al., 2014; Leung et al., 2014; Mukherjee et al., 2014; Checinska et al., 2015; Kettleson et al., 2015; Nordahl Petersen et al., 2015; Bokulich et al., 2016; Brooks et al., 2017; Täubel and Leppänen, 2017). Most studies are focused on bacteria and fungi, because of methodological limitations to profiling viruses. The few reports studying viral constituents of the MoBE targeted specific viruses in distinct BE such as intensive care units (ICUs) (Bramley et al., 2012).

MoBE has profound impacts on human health and wellbeing. Microbial pathogens are responsible for more than 400 million years of life lost annually worldwide (Fitzpatrick et al., 2019), some of which are results of transmission of pathogens via air, water, and surface contact in the BE (Madhav et al., 2017). It should be noted that the $\mathrm{BE}$ is considered as a major venue that facilitates the transmission of the novel coronavirus (SARS-CoV-2) (Allen and Marr, 2020; Prather et al., 2020), which is a pandemic that has infected millions and is still spreading rapidly. The resulting economic losses will be unprecedented. In addition, transmission in the $\mathrm{BE}$ is also responsible for the spread of influenza (e.g. by contacting contaminated objects) and Legionella (e.g. via inhalation of contaminated water droplets), leading to significant human and economic losses. Flu alone costs the US healthcare system an average of $\$ 11.2$ billion each year (Putri et al., 2018). During the 2019-2020 flu season, an estimated 16000 people have died of flu. The case-fatality rate of Legionnaires' disease, caused by Legionella, can be as high as 50\% in certain outbreaks (Prussin et al., 2017). The transmission of microbial pathogens in the $\mathrm{BE}$ is also manifested by the fact that every year there are 1.7 million hospital acquired infections (HAIs) in the US, resulting in 99000 related deaths every year (Curtis, 2008). Moreover, about $21 \%$ of asthma cases in the US can be attributed to dampness and mold in the BE, particularly residential homes, costing $\$ 3.5$ billion annually (Mudarri and Fisk, 2007). It was found that reduced microbial diversity in the $\mathrm{BE}$ is associated with the development of asthma (Ege et al., 2011). In addition, MoBE may affect immune system functions through interactions with the host-associated microbiota, and further impact occupants' mental health (Hoisington et al., 2015). Having the simplistic assumption that microbiomes are "bad," people conventionally have attempted to suppress microbial growth and eradicate microorganisms from the $\mathrm{BE}$. However, the MoBE research community has become increasingly aware of the beneficial roles "good" microbiomes play in preventing diseases (Turnbaugh et al., 2006; Round and Mazmanian, 2009; Bultman, 2014; Hsiao et al., 2013; Ridaura et al., 2013; Lowry et al., 2016; Dai et al., 2017). One example is that exposure to microbiomes from dogs (Liu et al., 2015) and traditional farm-type environments (Kirjavainen et al., 2019) early in life has been linked to reduced probability of developing asthma.

To develop strategies for sustainable management of the $\mathrm{BE}$ to promote public health and well-being, it is essential to understand the processes underlying the interactions between the microbiomes, BE, and occupants. To this end, numerous studies have been conducted to characterize the $\mathrm{MoBE}$ and subsequently its linkages to the attributes of $\mathrm{BE}$ design and operation, as well as occupant behaviors. BE, occupants, and microbiomes constitute a system of ecosystems with extensive interactions that impact one another. The composition and dynamics of the MoBE, which is a frequent target for microbial control, have been found to be impacted considerably by the occupants as well as BE design and operation. This review summarizes our current understanding of how BE design and operation, and occupant behaviors and activities interact to shape MoBE. The review also discusses the opportunities, challenges and future research directions in the field of MoBE to move beyond the basic characterization of MoBE in order to gain mechanistic understanding of the interactions between BE, occupants, and microbiomes at various spatiotemporal resolutions, which would support the development of transformative and effective intervention strategies toward healthy BE.

\section{Bibliographic overview}

\subsection{Co-authorship network by country}

To include relevant literature in the field of MoBE in this review, we searched and collected all published items in Web of Science (WOS) having the term "built environment" and "microbi*" in the abstract/title/keywords. A total of 1403 publications related to MoBE were collected from 1991 to February 2020. Since MoBE is likely distinct geographically, the publication data was uploaded to VOSviewer to create a co-authorship network by country (van Eck and Waltman, 2010), showing that authors who published work in the field of MoBE are from 95 countries. The number of countries with 5 or more MoBE-related publications is 46, indicating the concentration of MoBE research in a small number of countries (Fig. 1). Among the countries represented in the network, authors from the US contributed to more than $25 \%$ of all the publications on 
MoBE. More revealing is the observation that research collaboration is stronger between countries already with high levels of MoBE research, which are mostly conducted in developed countries (Fig. 1). For example, the US has a very high level of collaboration with Germany and Belgium in MoBE research. Given the potential differences in MoBE between developed and developing countries, it is necessary to expand MoBE search in developing countries to address issues of global impact, such as the transmission of pathogens in BE, which may differ considerably in countries with distinct BE design and operation attributes.

\subsection{Keyword co-occurrence network}

VOSviewer was also used to create a keywords cooccurrence network, which could be used to identify key components included for MoBE analysis (Lee and Su, 2010). A total of 3989 author keywords were identified in 1403 publications on the topic of MoBE. These keywords were reduced to 110 by using minimum occurrences of 5 , which was used to develop a co-occurrence network consisting of 110 keywords and 563 links (Fig. 2). As expected, microbiome, built environment, bacteria, and fungi are the four dominant keywords in the published items. In comparison, keywords related to specific BE attributes, such as air, surface, and water quality, have received less research attention and are not frequently investigated together with the microbiomes, indicated by the long distance between these keywords and the center of the network (Fig. 2). Given the significant impact of BE attributes on MoBE, the general lack of research efforts to linking $\mathrm{BE}$ attributes to MoBE indicates an important gap that needs to be closed in future studies (Kembel et al., 2012; Leung et al., 2014). Moreover, virus is absent as a keyword in the network, indicating that, despite the significance of viruses as a part of MoBE, few studies have investigated viruses as constituents of MoBE.

\section{Impacts of occupancy on MoBE}

The occupants of BE play an important role in shaping MoBE (Smith et al., 2013; Nice and Bole, 2016). It has been demonstrated that high occupancy increases the accumulation of human-associated microorganisms (Hospodsky et al., 2012; Kembel et al., 2012; Qian et al., 2012; Kembel et al., 2014; Meadow et al., 2014a; Meadow et al., 2014b; Miletto and Lindow, 2015; Ross and Neufeld, 2015; Dannemiller et al., 2016; Kang et al., 2018) and potential microbial transmission through increased social interactions, direct or indirect contact with surfaces, and air

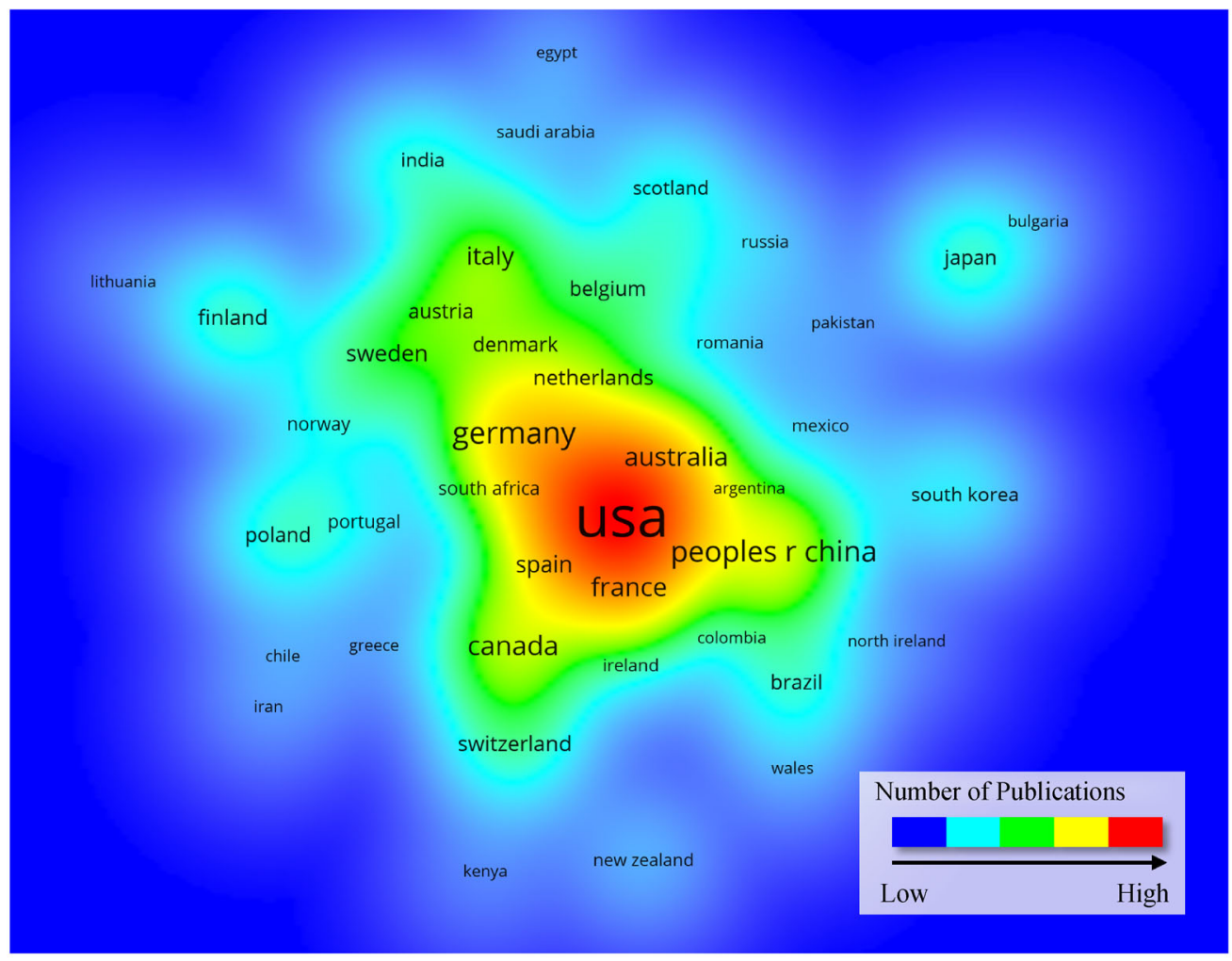

Fig. 1 Bibliometric map based on the network of co-authorship relationships among 46 countries, with the color of the network representing publication count by country. The distance between countries in the network represents the level of collaboration, i.e. the smaller the distance between the two countries, the greater number of publications contributed by authors from both countries. 


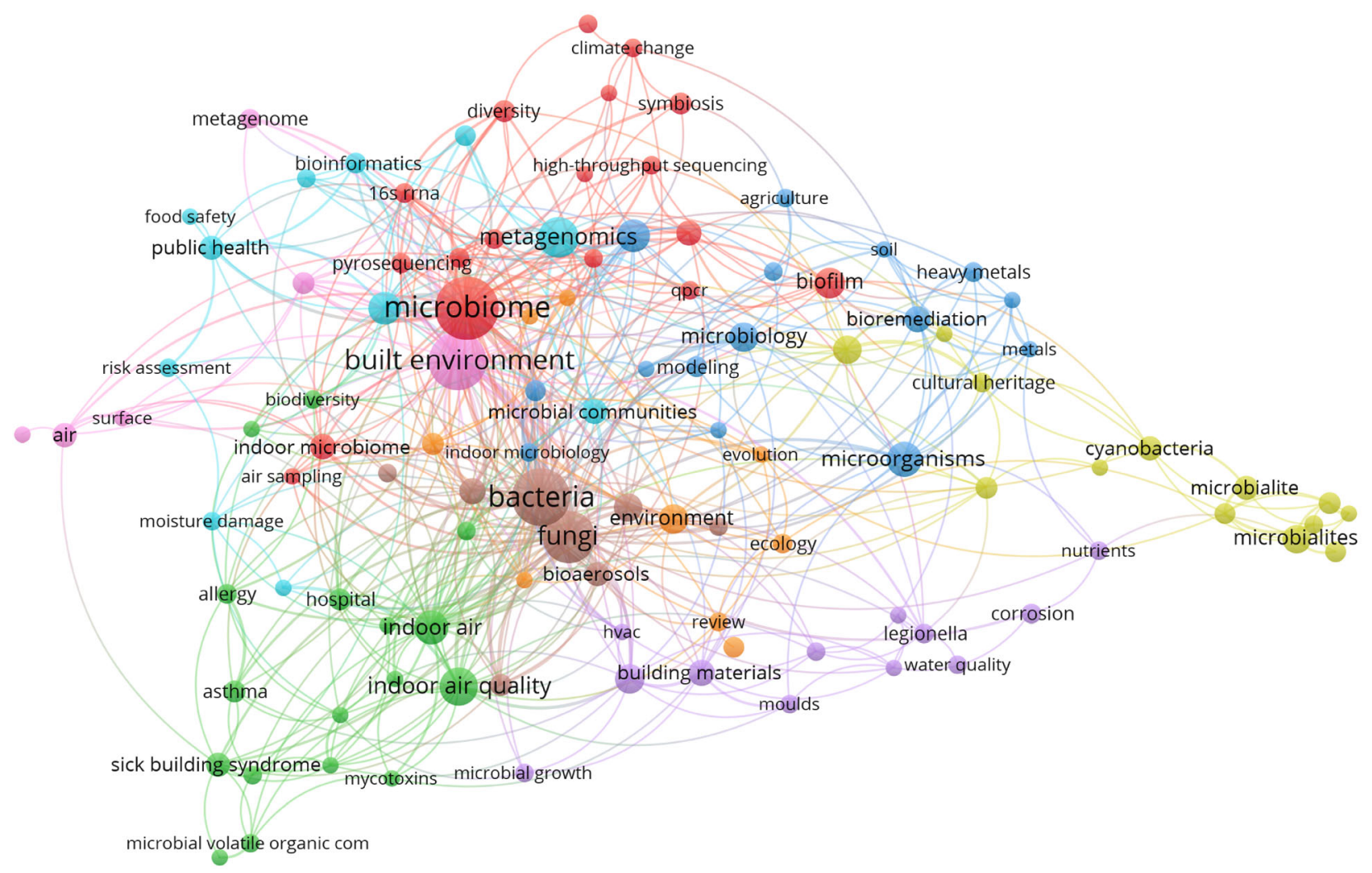

Fig. 2 Author keyword co-occurrence patterns in MoBE literature. Each circle represents a keyword. The size of the circle is defined as the occurrence frequency of the keyword measured in terms of publications. The distance between the circles is an indication of the number of co-occurrences - the shorter the distance between two keywords, the stronger the relationship is.

flow (Salathe et al., 2010; Andrews et al., 2014; Wood et al., 2014). The MoBE associated with indoor dust and surfaces are specifically enriched with microbial populations originated from the human skin, gut, oral, and urogenital microbiomes (Flores et al., 2011; Jeon et al., 2013; Adams et al., 2014; Lax et al., 2014; Leung et al., 2014; Meadow et al., 2014a; Afshinnekoo et al., 2015; Gibbons et al., 2015). This is expected as it is estimated that humans emit in the order of $10^{6}$ particles and $10^{7}$ bacterial genome copies per hour (Qian et al., 2012; You et al., 2013). It is worth noting that the microbial clouds emitted from individual human occupants could be different. For instance, people with contrasting health conditions exhibit distinct microbiomes (Hoisington et al., 2015; Lloyd-Price et al., 2016). The distribution of occupant-associated indoor microbiomes can also be linked to the duration that individuals spend in the BE and the type of activities performed (Dunn et al., 2013; Lax et al., 2014; Adams et al., 2015b; Meadow et al., 2015; Karkman et al., 2017; Luongo et al., 2017; Ross et al., 2017), which could partially explain the differences in MoBE of different functionalities including hospitals, residences, and schools (Meadow et al., 2015).

Occupant-associated microbiomes may disperse into the
BE via three pathways (Fig. 3): 1) direct human contact with surfaces; 2) emission of bioaerosols and particulates from human breath, skin, and hair; and 3) resuspension of indoor dust containing human-emitted microbiomes (Meadow et al., 2015). Previous studies have shown that occupants affect MoBE through desquamation and physical contacts with indoor surfaces (Lax et al., 2014; Adams et al., 2015a; Wood et al., 2015) as the primary pathways. Both the frequency (Flores et al., 2013) and the nature of human contact (e.g. with skin, or with shoes on floor or carpet, or release of gut-associated microbiomes in washrooms) (Flores et al., 2011; Kembel et al., 2014; Meadow et al., 2014b; Mukherjee et al., 2014; Gibbons et al., 2015; Wood et al., 2015) can affect the composition of microbiomes in different indoor areas and on different surfaces within a single BE. For instance, desk surfaces in classroom are associated with indicator taxa related to Streptococcus species that are more commonly found in human skin and oral samples. Walls are found to be associated with indicator taxa from airborne bacterial assemblages such as Sphingomonas and Alicyclobacillus species, while floors are more likely to harbor non-human environmental bacterial populations (Meadow et al., 2014b). Revealed by longitudinal analysis, surfaces in 


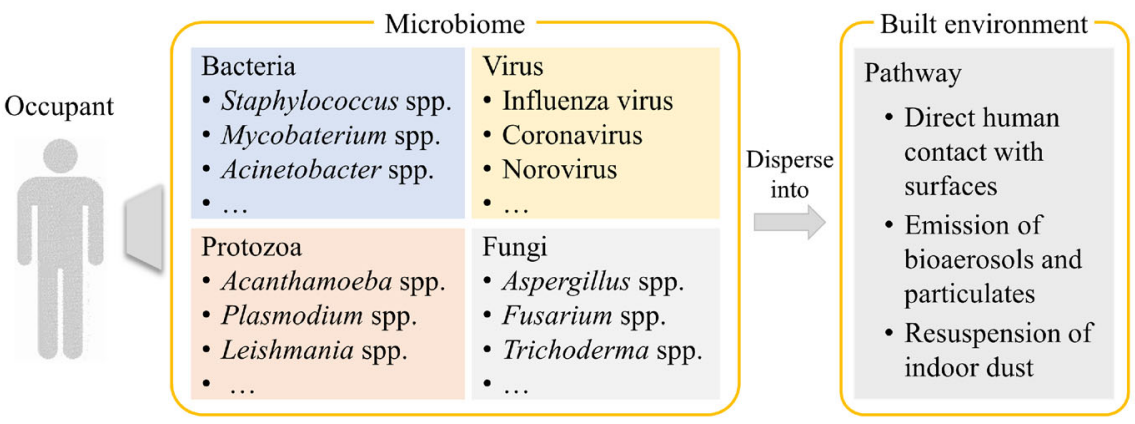

Fig. 3 Impacts of occupancy on MoBE.

public areas (e.g. fitness centers, airplanes, public transit, etc.) with more frequent contacts exhibit greater temporal variations in their microbial communities (Wood et al., 2015), as compared with a private BE (e.g. residential unit). In addition, occupant movements may cause resuspension of settled dust particles (Hospodsky et al., 2012; Qian et al., 2012; Adams et al., 2015a; Yamamoto et al., 2015), and introduce exogenous microbial populations from outdoor environments (Fujimura et al., 2010; Heydenreich et al., 2012; Adams et al., 2015b; Barberán et al., 2015), which can redistribute and reshape MoBE. These findings reveal considerable variations in MoBE at fine spatiotemporal resolutions, pointing to the need for surveying MoBE at much finer resolutions than those of individual rooms and seasons, which are typically lacking in MoBE studies in the literature.

Given the significance of occupants in shaping MoBE, it is fundamentally important to incorporate occupant behaviors and activities into the analysis of MoBE. Up till now, few studies have attempted to link occupants to MoBE, which is likely due to the lack of technologies suitable for the monitoring and characterization of occupant movements.

Previous studies have further shown that the impacts of occupants on MoBE are mediated by the design and operation of the BE. For instance, architectural design attributes influence occupant behaviors and activities such as the contact and use patterns (Beans, 2016; Brown et al., 2016), human interactions (Purcell, 1987; Dunn et al.,
2013), how and where occupant-associated microbiomes are emitted and deposited (Kembel et al., 2014; Meadow et al., 2014a), properties of building surface materials (affecting the colonization of human-emitted microbiomes), and temperature (affecting occupant behaviors). Next, a detailed review of how the design and operation attributes of BE would influence MoBE is presented.

\section{Impacts of BE attributes on MoBE}

The built environment is a reservoir of diverse microorganisms and provides an environment for microbial colonization, succession, and transmission. The attributes of $\mathrm{BE}$ design and operation have a direct influence on the MoBE (Fig. 4). Further, these attributes indirectly affect MoBE via impacts on occupant behaviors and activities. For instance, the building layout directly affects the movements and activities of occupants, which subsequently influences how occupant-associated microbiomes are dispersed in the BE (Hathway et al., 2011). The choice of design will also influence sunlight exposure, which could play roles in the inactivation of microorganisms (Couret et al., 2013). Ventilation (e.g., the exchange with outdoor air) may also have impact on indoor microbiomes in both diversity and abundance. The direction of airflow will dictate the distribution of aerosols and particulates which are the carriers of microorganisms. Temperature and moisture represent two interrelated attributes in the built

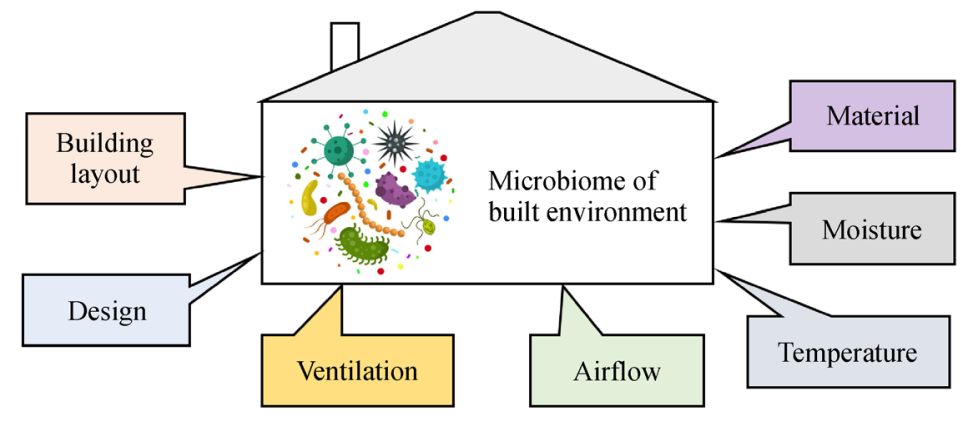

Fig. 4 Impacts of BE attributes on MoBE. 
environment as temperature differences are typically linked to humidity gradients. Controlling moisture and temperature in the $\mathrm{BE}$ is believed to be important to suppress the growth of molds, which are significant constituents of MoBE. More importantly, the coupled influence of moisture and building material properties (e.g. surface roughness and $\mathrm{pH}$ of material), together with human contact and activities, will significantly influence microbial growth. Often neglected is the contribution of plumbing systems to MoBE, as bacteria such as Legionella can be transported from the water in plumbing systems to the air, and subsequently transmitted further via the ventilation systems.

\subsection{Functional characteristics of $\mathrm{BE}$}

The functionalities of $\mathrm{BE}$ have been found to directly impact the composition of MoBE. Previous studies analyzed bacterial communities in dust samples collected from $155 \mathrm{BE}$ locations to reveal how $\mathrm{BE}$ design attributes impact the MoBE (Kembel et al., 2012; Kembel et al., 2014). It was found that bacterial communities in restrooms were dramatically different from those in other rooms. Further, the set of bacterial taxa found in spaces with high occupancy and high degree of connectedness to other spaces exhibit significant differences from those found in spaces with low occupancy and low degree of connectedness. Another study examined microbiome data acquired from various built environments with different functionalities, including apartment buildings, food processing facilities, hospitals, residential kitchens, art museums, and university buildings (Adams et al., 2015a). The analysis identified variations in microbial communities among different building types, which supports the hypothesis that the function of BE would impact the indoor microbial communities.

Despite the numerous studies on MoBE, it remains unclear how the functions of BE would impact MoBE. This ambiguity may stem from two aspects. First, the functional characteristics of BE likely impact the MoBE through many interrelated processes. The functionality of a particular BE would typically dictate various design attributes of the $\mathrm{BE}$, including the choices of sunlight admission, ventilation pattern, building materials, and heating, ventilation, and air conditioning (HVAC) systems. These choices collectively would influence the environmental conditions (e.g. temperature, humidity, lighting, and airflow) critical for the colonization, succession, and also transmission of the MoBE. Second, the functional characteristics of BE would likely also impact occupant activities (e.g. specific user groups, occupant density, and movement) (Zifferblatt, 1972). Given the significance of occupants and building characteristics in shaping MoBE, it is important to study the building, occupant, and microbiome as an integrated system to identify processes involved in the development of MoBE. In the following sections, we will review the scientific literature focusing on the linkages between design and operational attributes and MoBE.

\subsection{Building material}

All building materials may be subject to microbial colonization (Warscheid and Braams, 2000; Cutler and Viles, 2010; Jurado et al., 2014; Coutinho et al., 2015; Dedesko and Siegel, 2015; Guerra et al., 2019; Hu et al., 2019). Studies have been conducted to identify the microorganisms readily present on building materials in the BE. One group of microbial populations most frequently identified in building materials are those belonging to Penicillium (Andersson et al., 1997; Tuomi et al., 2000; Doll, 2002; Hyvärinen et al., 2002; Rintala et al., 2002; Andersen et al., 2011; Verdier et al., 2014). Aspergillus species are often found on ceramic-type materials as well as surfaces of paint and glue (Hyvärinen et al., 2002; Andersen et al., 2011). Gypsum-type materials may facilitate the development of Stachybotrys, another indication of the selectivity of microbial colonization on building materials (Pasanen et al., 1992; Andersson et al., 1997; Hyvärinen et al., 2002; Andersen et al., 2011).

As a result, the susceptibility of different building materials to microbial colonization has been evaluated. Among bio-based construction materials, chipboard was found to be the most susceptible to mold growth and wood the least (Stefanowski et al., 2017), while plant aggregates would make earth-based materials more sensitive to fungal growth (Laborel-Préneron et al., 2018; Simons et al., 2019). Compared with cement-stabilized earth blocks, bricks as wall materials were shown to be more susceptible to fungal growth (Udawattha et al., 2018). Some studies suggest that high levels of copper in pipe materials inhibit Legionella survival and growth in indoor plumbing systems (van der Kooij et al., 2005; Proctor et al., 2017), while others found increased persistence of Legionella in biofilms formed on copper plumbing materials (Buse et al., 2014). A significant portion of indoor surfaces, including textiles, have incorporated metal nanoparticles to discourage fungal and bacterial growth (Chen et al., 2018; da Silva et al., 2019). Recently, the green wall and green roof concepts have also been introduced into buildings. The plants may introduce source microorganisms, moisture, and nutrition that support microbial growth. It is known that indoor plants can contribute substantially to the microbial abundance and diversity in the BE (Mahnert et al., 2015). It is thus important that new materials being continuously developed for applications in the BE need to be evaluated for their impact on MoBE as part of the product evaluation process.

The properties of the materials, coupled with lighting, heating, cooling, humidity and ventilation as well as the 
occupants and their activities, can considerably affect MoBE. Building material properties may contribute to the microbial colonization via two ways. First, the ingredients of the building materials can provide potential substrates and nutrients for the colonized microbiomes (Lugauskas et al., 2003; Vacher et al., 2010). For instance, because cellulose-based materials can be metabolized by a number of microbial populations (Gutarowska, 2010; Hoang et al., 2010), they are more susceptible to microbial colonization and growth than inorganic materials such as gypsum, mortar, and concrete. Addition of carbon sources (e.g. carboxylmethyl cellulose) or emulsion paint is known to provide potential substrates for microbial growth (Ayerst, 1969; Grant et al., 1989). Second, most building materials, such as wallpaper glue, paint, grease, paper, textile, and wood products, are characterized with high porosity and surface roughness. The rough and porous surface may facilitate the adherence of dust and organic compounds resulting from the activities in the buildings. In addition, porous material may also retain sufficient moisture (Hoang et al., 2010). As a result, rough and porous building materials could facilitate microbial growth due to increased levels of organics and moisture (Lax et al., 2019). However, it is suggested that microorganisms retained by porous materials may be immobilized, making it less likely for these microorganisms to subsequently interact with the BE (Abrishami et al., 1994; Ak et al., 1994). Therefore, the influence of porous materials on MoBE needs further investigation.

\subsection{Heating, ventilation, and air conditioning (HVAC)}

\subsubsection{Temperature}

Indoor air temperature has been shown to have impacts on the abundance of indoor microbial community. However, the relationship between temperature and MoBE is unclear as some studies found positive correlations as greater abundance of indoor microbiomes was associated with higher temperature (Ponsoni and Raddi, 2010; Frankel et al., 2012; Kembel et al., 2012) while other studies observed inverse correlations (Frankel et al., 2012; Dannemiller et al., 2016). The potential explanation to the conflicting findings is twofold. First, most BE are maintained at a temperature range between 60- and 80degrees Fahrenheit for human comfort. Although different types of microbial populations have different temperature ranges for growth, many microorganisms grow well in this indoor temperature range (Tang, 2009). As a result, the temperature alone in the $\mathrm{BE}$ may not be considered as a factor to explain the variations in MoBE. Second, temperature may impact other parameters in BE such as moisture, as well as occupant behaviors and activities, which exert indirect impacts on microbial colonization and transmission. These indirect impacts made it very difficult to quantify the impact of temperature on MoBE.

\subsubsection{Moisture}

Moisture significantly influences the survival (Jump et al., 2007; Tang, 2009; Zhao et al., 2012; Hoeksma et al., 2015), activity (Dannemiller et al., 2017; Hegarty et al., 2018), and composition of the MoBE (Pessi et al., 2002; Kembel et al., 2012; Dannemiller et al., 2016). The moisture in BE may come from a variety of sources including indoor water vapor content, weather events, plumbing problems, and leaks from building envelopes and roof systems. Temperature gradients are a less obvious source of moisture, which is often overlooked and ignored. However, at locations where relatively warm and moist air is in contact with relatively cold surfaces, water condensate may occur on building surfaces (Hänninen, 2011), which might occur frequently in air-conditioned buildings.

Moisture in the air and on the surface may impact the MoBE in different ways. Relative humidity is often used to measure moisture saturation in the air. Low relative humidity will increase the possibility of aerosolization of microorganisms on indoor surfaces and the resuspension into air due to occupant movements (Frankel et al., 2014; Hyytiäinen et al., 2018; Wu et al., 2018). Low relative humidity will also increase the potential for the aerosols to stay aloft longer and travel farther (Wolkoff, 2018). On the other hand, high relative humidity is conducive to microbial survival and activity on surfaces (Jump et al., 2007; Tang, 2009; Zhao et al., 2012; Hoeksma et al., 2015), and facilitates the direct contact transfer of microorganisms from fomite to occupants (Lopez et al., 2013). Microenvironments within surfaces, e.g., high relative humidity in the carpet, can create niches for microbial growth and further influence microbial transfer from surfaces (Dannemiller et al., 2017). In this sense, localized relative humidity in a building needs to be effectively controlled to reduce the dispersal and transmission of microorganisms in the BE (Wolkoff, 2018).

Moisture at the material surface is assessed as equilibrium relative humidity (ERH). When the ERH reaches certain thresholds, the surface of building materials could become the target of microbial growth. For instance, it is more conducive for microbial growth when the ERH is greater than $70 \%$ for wooden materials, $85 \%$ for gypsumboard, and around $90-95 \%$ for cementitious and concrete materials (Riva et al., 2014; Adams and Lymperopoulou, 2018). High ERH will facilitate the germination and proliferation of mold on building materials (Pasanen et al., 1992; Kembel et al., 2012; Green, 2014; Lau and Chamberlain, 2016; Dade-Robertson et al., 2017). The surface relative humidity is seldom the same as that of the air since the temperature of surface is usually not the same 
as that of the air. Therefore, efforts to control the indoor air relative humidity alone will not likely guarantee optimal control of mold growth on surfaces (Tsongas and Riordan, 2016).

\subsubsection{Ventilation}

Ventilation affects indoor temperature, humidity, airflow rates, and carbon dioxide levels which could influence the compositions of MoBE and may select for the survival of specific microbial taxa (Kembel et al., 2012; Kembel et al., 2014; Leung et al., 2014; Kettleson et al., 2015). The most direct impact of ventilation on MoBE is to facilitate or impede outdoor microbiomes from entering the BE. This argument is supported by studies showing microbial communities in mechanically ventilated rooms exhibit significant differences from those with natural ventilation (Kembel et al., 2012; Adams et al., 2013; Adams et al., 2014; Meadow et al., 2014a). For example, differences in microbial community composition were apparent between dust samples collected from a mixed-use building with half of the offices using natural ventilation and those of the other half using a conventional mechanical system (Bragoszewska et al., 2018). Compared with mechanically ventilated rooms, naturally ventilated rooms had indoor microbiomes more similar to those of the outdoor environment (Kembel et al., 2012; Meadow et al., 2014a), because microbes from the outdoors are more likely to enter the naturally ventilated rooms (Adams et al., 2013; Robertson et al., 2013; Meadow et al., 2014a).

In contrast, mechanical ventilation usually uses filters to prevent some of the outdoor microbes and particulates from entering the BE. Conventional air filters are effective in removing particles less than $0.1 \mu \mathrm{m}$ in diameter via diffusion and particles larger than $1 \mu \mathrm{m}$ in diameter with impaction, which makes it effective against bacterial and fungi (Hospodsky et al., 2015) but less effective against some viruses such as influenza due to their size ranges (Lindsley et al., 2010). It has been shown that appropriate ventilation with sufficient air exchanges and/or directed air flow can effectively reduce the overall concentrations of airborne microbial pathogens (Memarzadeh, 2013), thus reducing disease transmission risks (Chartier and PessoaSilva, 2009; Hobday and Dancer, 2013). However, inappropriate ventilation, such as high ventilation rates with high turbulence, can retain particulates and associated microbial populations in the air, thus may negatively impact health (Carlton et al., 2019).

Natural ventilation introduces extra outdoor air to the $\mathrm{BE}$ and is proven to mitigate the sick building syndrome (Seppanen and Fisk, 2002). This is likely due to the introduction of more diverse indoor bacterial communities into BE, which has shown positive health effects (Kembel et al., 2012). However, natural ventilation also introduces undesirable contaminants such as allergens, which is a challenge to the broader application of natural ventilation, particularly in BE with vulnerable occupants (Kovesi et al., 2009).

\subsection{Sunlight}

The antiseptic effect of sunlight was discovered in the late 1800s (Downing and Blunt, 1878; Bazzoni, 1914). Such an effect has been particularly studied in healthcare facilities (Nightingale, 1863; Kundsin, 1988; Medeiros et al., 2015). Studies have also been conducted to illustrate how sunlight (full-spectrum) and light of specific spectrum affect monoculture microorganisms as well as complex microbial communities. It was found that the survival and activity of bacterial or fungal monocultures were negatively affected by exposure to sunlight (Fonseca and Tavares, 2011; Hobday and Dancer, 2013; Hessling et al., 2017), ultraviolet light (Kundsin, 1988; Besaratinia et al., 2011; Goldman and Travisano, 2011; Dai et al., 2012; Oppezzo, 2012; Takada et al., 2017), and light of blue or red wavelengths (Ondrusch and Kreft, 2011; Deng et al., 2012; Lins de Sousa et al., 2015; Maclean et al., 2016).

The effect of light on microbial communities including those in house dust or on human skin was also reported in the literature (Patra et al., 2016; Prescott et al., 2017; Fahimipour et al., 2018). Visible or UV light can reduce the number of live bacteria and lead to less humanassociated bacterial communities in the BE (Fahimipour et al., 2018). Similarly, increased illumination in hospital rooms was found to reduce human-associated taxa in indoor surface bacterial communities (Hartmann et al., 2004). In particular, sunlight/UV was found to be effective in the inactivation of viruses (Sandhu and Singh, 2009; Tang, 2009; Hobday and Dancer, 2013). Compared with viruses, bacteria may be more resistant to sunlight/UV exposure (Goldman and Travisano, 2011).

Given the disinfection effect of sunlight, it could be expected that areas of $\mathrm{BE}$ with greater sunlight exposure would have lower microbial activity, which is a desirable outcome when microbial control is a priority. $\mathrm{BE}$ design and operation can take advantage of the disinfection capacity of sunlight by strategically enhancing sunlight exposure in areas with greater risks of microbial contamination and transmission, such as conference rooms and bathrooms. The effectiveness of the strategy to exploit sunlight for the control of MoBE, however, needs to be further validated in field studies.

\subsection{Premise plumbing systems}

Premise plumbing systems include the portions of the potable water distribution system in the building beyond the connection to the water mains. A front line of human exposure, premise plumbing, is also an ideal ecological niche for opportunistic pathogens such as Legionella, Mycobacterium, and Pseudomonas. As a result, bacterial 
levels in the premise plumbing systems were found to be orders of magnitude higher than in the water main (NRC, 2006).

Colonization of opportunistic pathogens was reported in various locations in premise plumbing systems including cold and hot water reservoirs (Falkinham et al., 2008), tap and shower (Feazel et al., 2009; Perkins et al., 2009), eye wash stations (Paszko-Kolva et al., 1998), and water filters (Falkinham, 2010). The presence of microbial colonization in premise plumbing systems are also documented in hospital buildings (Thomas et al., 2006; Rivera et al., 2007; Arvand et al., 2011; Brown-Elliott et al., 2011) and hotels (Borella et al., 2005; Mouchtouri et al., 2007; Bonetta et al., 2010). The additional growth time during overnight water stagnation, which is characteristic of premise plumbing, was found to significantly increase the abundance of Legionella, Mycobacteria, and other bacterial populations in premise plumbing (Wang et al., 2012). The microbial populations in premise plumbing systems can spread across the building through drains (Kotay et al., 2017) and aerosolized water droplets generated at faucets and showerheads (Kline et al., 2004; Falkinham et al., 2008; Thomson et al., 2013). Once entering the BE, pathogens such as Legionella pneumophila can persist in building ventilation systems and infect building occupants (Yu and Stout, 2000; Borella et al., 2004).

The colonization and growth of opportunistic pathogens in premise plumbing systems are also affected by water treatment in the building. Point-of-use filtration, albeit being relatively costly and require maintenance (Marchesi et al., 2011), was found to be very effective in reducing $L$. pneumophila and $M$. avium concentrations in filtered water (Sheffer et al., 2005; Marchesi et al., 2011; Williams et al., 2011). However, filters were found to be a potential source of microbial growth after saturation (Falkinham, 2010). Other features of the premise plumbing were also found to influence microbial colonization. For example, the presence of Legionella was found to be less prevalent in newly constructed buildings (Mathys et al., 2008). Electronic faucets prevent the touching of the contaminated taps and therefore are often considered less susceptible to microbial growth compared with the manual faucets. However, it was found that the electronic faucets were more commonly contaminated with Legionella species (Sydnor et al., 2012), P. aeruginosa (Yapicioglu et al., 2012), and other bacteria in hospitals. Evidently, much remains to be learned how MoBE is linked to the premise plumbing systems.

\subsection{Cleaning and disinfection}

Cleaning and disinfection practices are routinely performed with reducing occupants' exposure to harmful microorganisms in BE as one of the primary goals. These practices include removal of airborne microbes through ventilation and filtration, and inactivation of microbes in indoor air and on surfaces through the application of UV irradiation and chemical disinfectants.

UV irradiation has been shown as an effective technology for the inactivation of microbes in the BE. The mechanism of UV disinfection is attributed to the damage of UV irradiation to the DNA of living organisms and render them unable to replicate, thus noninfectious. Typically, UV disinfection of indoor air is conducted by irradiation of the upper-level of a room and taking advantage of rapid vertical mixing of air for complete disinfection of the air in that environment (Brickner et al., 2003). To prevent accidental exposure to UV by occupants, the UV lamps need to be specially louvered for in-room use (Sliney, 2013). In addition to the exposure risk to radiation, UV with wavelength below $242 \mathrm{~nm}$ generates ozone which also imposes exposure risks to occupants, requiring UV application to follow established guidelines (ASHRAE, 2019).

UV irradiation is also effective in the inactivation of microorganisms on indoor surfaces to achieve comprehensive disinfection of the $\mathrm{BE}$, which is practiced mostly in healthcare and laboratory settings. The effectiveness of UV disinfection has been demonstrated by significant reductions in healthcare-associated infections (HAIs) when UV irradiation was added to the standard cleaning regimen in hospitals (Levin et al., 2013; Miller et al., 2015; Nagaraja et al., 2015; Weber et al., 2016; Anderson et al., 2017). UV irradiation has also been applied on cooling coils to reduce microbial growth and endotoxin production in the ventilation system (Menzies et al., 2003), again supporting its effectiveness in microbial control in the BE.

Chemical disinfectants are also effective in inactivating microbial populations on indoor surfaces. It should be noted that the cleaning/disinfecting chemicals could be potential sources of volatile organic compounds (VOCs) and secondary aerosols in the indoor air (Nazaroff and Weschler, 2004). These aerosolized chemical disinfectants may present acute exposure risks to indoor occupants. Another potential issue with the use of chemical disinfectants is that the very presence of antimicrobial chemicals increases the risk of producing resistance strains (Aiello and Larson, 2003), which is an emerging public health concern. Moreover, due to the lack of selectivity in inactivating microbes, common disinfection practices would indiscriminately kill beneficial microorganisms, which demands the development of disinfection strategies that specifically target harmful microbial populations.

With the ongoing pandemic of COVID-19, the deployment of chemical disinfectant and UV irradiation has increased dramatically in various BE. It is important to investigate the impacts of intensified disinfection on MoBE and subsequent effects on the health of occupants. 


\section{Discussion}

There are tremendous opportunities in the fledging research area of MoBE that will benefit disciplines including public health and building engineering in particular. In this section, we discuss the challenges and possible solutions to in-depth understanding of the complex interactions between the built environment, occupants, and microbiomes.

BE, occupants, and MoBE constitute a system of ecosystems with extensive interactions that impact one another. Previous studies have demonstrated that a significant portion of MoBE originates from the occupants. The quantity and composition of occupant-associated microorganisms are dictated to a large extent by characteristics of occupant behaviors, which are greatly influenced by $\mathrm{BE}$ attributes including layout, function, and indoor environmental conditions. In addition to occupant behavior, $\mathrm{BE}$ attributes further influence the survival and dynamics of the MoBE, which subsequently determine the occupants' exposure to the MoBE. These interactions are evidently manifested in the transmission of SARS-CoV-2. In BE, SARS-CoV-2 is derived exclusively from occupants. Thus, the concentration of SARS-VoV-2 in BE is closely linked to occupant behaviors, such as facemaskwearing, hand-washing, and social distancing (Prather et al., 2020). Accordingly, these behavioral patterns could be influenced by BE attributes including indoor temperatures conducive to mask wearing, availability of handwashing facilities, and adequate occupant capacity (West et al., 2020). BE attributes, particularly ventilation and disinfection practices, further influence the viability and concentration of SARS-CoV-2, and subsequently the exposure risks of occupants (Allen and Marr, 2020). The ongoing COVID-19 pandemic highlights the significance of interactions between BE, occupants, and MoBE.

Despite the progress made in characterizing MoBE, significant gaps are identified in this review, including: 1) The need to extend MoBE studies to more developing countries in order to be representative of the potential diversity in MoBE related to socioeconomic disparities; 2) The need to characterize MoBE with linkages to building attributes in order to elucidate the mechanisms driving MoBE; 3) The need to characterize MoBE at a finer spatiotemporal resolution to capture the dynamics of MoBE, particularly under the influence of occupant behaviors; and 4) The need to determine the impacts of occupant behaviors on MoBE. These knowledge gaps stem from three major technical challenges: 1) lack of effective methods to monitor and model the built environment and occupant behaviors at fine resolutions to enable quantitative, sensitive, and reproducible experimental design and data analysis; 2) lack of efficient tools to monitor the spatiotemporal patterns of indoor microbiomes that are present in spatially and functionally distributed compo- nents of the built environments and occupants; and 3) lack of approaches to integrating data of the built environment, occupants, and microbiomes to identify transmission and exposure pathways. Monitoring the built environment and occupant activities is a prerequisite for understanding their influence on MoBE, which is critical for identifying transmission modes and exposure pathways of specific pathogens in the BE. Fine-resolution representations of the built environment and occupant behaviors are required for quantitative, sensitive, and reproducible modeling of MoBE, given its spatiotemporal dynamics at fine resolutions. Previous studies have fallen short of closing these knowledge gaps largely because of these technical challenges. Therefore, as a critical first step, efforts should be devoted to developing capabilities for monitoring the built environment at sufficient resolutions so that understanding of fine-resolution processes that structure microbiome dynamics is possible.

The MoBE is an inherently transdisciplinary field at the nexus of building science, environmental microbiology, public health, material sciences, sensors, and data science, just to name a few. Given the multidimensional nature of data for MoBE characterization, we call for the development and application of the following approaches to address research challenges in this field: 1) data-driven approaches to monitor the built environment and occupants by integrating advanced techniques such as building information modeling and internet-of-things (IoT) based sensing; 2) modeling-informed approaches for spatiotemporal sampling and characterization of MoBE at optimized resolutions; and 3) approaches integrating transport modeling with metagenomics and metatranscriptomics profiling to predict microbial dynamics, metabolic activities, and transmission pathways. The integration of new tools for sensing, modeling, and monitoring will provide unprecedented data at fine resolutions to gain new insights by: 1) guiding sampling for meaningful data collection; 2) identifying linkages between the built environment attributes, occupant behaviors, and MoBE characteristics; and 3) linking the dynamics of the built environment, occupants, and microbiomes to transmission and exposure pathways. Future efforts are needed to advance MoBE research from basic characterization (e.g. what microorganisms are there) toward modeling and prediction (e.g. how built environment attributes and occupant activities contribute to the dynamics of specific microbial populations, and how it may reciprocally affect the built environment and occupants).

In today's society, the communities and cities are increasingly connected with the built environment and natural environment tightly coupled, making it necessary to study the microbiomes, environments, and human interactions at a broader scale to gain new knowledge and insights to promote the health of the society as a whole. This pertains to an interesting and important question: how do activities at the community- and city-scales impact 
MoBE, and how does MoBE influence the inhabitants ranging from small scales (individual people) to large scales (communities and cities). Findings at these scales will have greater significance beyond individual built environments as most public health concerns are better addressed at the community scale and beyond. There were attempts to investigate MoBE at larger scales. In one study (Robertson et al., 2013), a baseline assessment was conducted for the microbiomes in the New York subway system. Results from this study could lead to potentially important applications, including infectious disease surveillance, bioterrorism threat mitigation, and communityscale public health management. However, it remains a challenge to the application of high-dimensional microbiome data integrated with community behavioral information such as mobility as well as environment monitoring data.

Based on the review of current literature, we suggest developing the ability to predict the dynamics of MoBE to serve the needs of engineering practitioners, city planners, and public health professionals. Previous studies have identified potential correlations between the MoBE and attributes of the built environment (e.g. geographic location, design, occupancy, ventilation rate and type), with various levels of uncertainties and inconsistency notwithstanding. It remains very challenging, if not impossible, to predict MoBE profiles in even small-scale buildings with due accuracy in real-time. It would be an ambitious, yet beneficial, call to develop capabilities to predict MoBE dynamics aided with emerging technologies of real-time sensing and data analytics, which will have great significance in the understanding and control of microbial transmission pathways in the built environment, an urgent issue of current public health concern.

\section{Conclusions}

Humans spend most of their time in the built environment with a vast diversity of microorganisms. Activities of the occupants and attributes of the built environment will impact the colonization, succession, and transmission of these microorganisms, which will in turn influence the built environment and human health. This review summarizes our current understanding of the complex interactions among the built environment, human activities, and microbiomes of the built environment, with an emphasis on how the built environment coupled with human activities impact the microorganisms. This review highlights the importance of advancing our understanding of the interrelationships among microorganisms, the built environment, and its occupants. Further, we call for the development and application of transdisciplinary approaches for the sensing and monitoring of buildingoccupant-microbiome interactions at sufficiently fine spatiotemporal resolutions to enable capacity development for the modeling and prediction of MoBE. These capabilities will support the goal toward developing healthy built environments that are both sustainable and resilient to detrimental microorganisms, particularly infectious pathogens. Future efforts are also needed to expand MoBE research from individual rooms and buildings to the scales of communities and cities, which will advance our understanding of the microbiome-human-environment ecosystem at a scale more relevant for the development of sustainable, healthy, and resilient communities as an ultimate goal.

Acknowledgements This work is partly supported by US National Science Foundation (Award No. 1952140 and 2026719). Any opinions, findings recommendations, and conclusions in this paper are those of the authors, and do not necessarily reflect the views of US National Science Foundation.

\section{References}

Abrishami S H, Tall B D, Bruursema T J, Epstein P S, Shah D B (1994). Bacterial adherence and viability on cutting board surfaces. Journal of Food Safety, 14(2): 153-172

Adams R I, Bateman A C, Bik H M, Meadow J F (2015a). Microbiota of the indoor environment: A meta-analysis. Microbiome, 3: 49

Adams R I, Bhangar S, Dannemiller K C, Eisen J A, Fierer N, Gilbert J A, Green J L, Marr L C, Miller S L, Siegel J A, Stephens B, Waring M S, Bibby K (2016). Ten questions concerning the microbiomes of buildings. Building and Environment, 109: 224-234

Adams R I, Bhangar S, Pasut W, Arens E A, Taylor J W, Lindow S E, Nazaroff W W, Bruns T D (2015b). Chamber bioaerosol study: outdoor air and human occupants as sources of indoor airborne microbes. PLoS One, 10(5): e0128022

Adams R I, Lymperopoulou D L (2018). Lessons learned when looking for non-neutral ecological processes in the built environment: the bacterial and fungal microbiota of shower tiles. bioRxiv: 413773

Adams R I, Miletto M, Lindow S E, Taylor J W, Bruns T D (2014). Airborne bacterial communities in residences: similarities and differences with fungi. PLoS One, 9(3): e91283

Adams R I, Miletto M, Taylor J W, Bruns T D (2013). Dispersal in microbes: fungi in indoor air are dominated by outdoor air and show dispersal limitation at short distances. ISME Journal, 7(7): 12621273

Afshinnekoo E, Meydan C, Chowdhury S, Jaroudi D, Boyer C, Bernstein N, Maritz J M, Reeves D, Gandara J, Chhangawala S, Ahsanuddin S, Simmons A, Nessel T, Sundaresh B, Pereira E, Jorgensen E, Kolokotronis S O, Kirchberger N, Garcia I, Gandara D, Dhanraj S, Nawrin T, Saletore Y, Alexander N, Vijay P, Henaff E M, Zumbo P, Walsh M, O'mullan G D, Tighe S, Dudley J T, Dunaif A, Ennis S, O'halloran E, Magalhaes T R, Boone B, Jones A L, Muth T R, Paolantonio K S, Alter E, Schadt E E, Garbarino J, Prill R J, Carlton J M, Levy S, Mason C E (2015). Geospatial resolution of human and bacterial diversity with city-scale metagenomics. Cell Systems, 1(1): 72-87

Aiello A E, Larson E (2003). Antibacterial cleaning and hygiene products as an emerging risk factor for antibiotic resistance in the 
community. Lancet. Infectious Diseases, 3(8): 501-506

Ak N O, Cliver D O, Kaspar C W (1994). Decontamination of plastic and wooden cutting boards for kitchen use. Journal of Food Protection, 57(1): 23-30

Allen J G, Marr L C (2020). Recognizing and controlling airborne transmission of SARS-CoV-2 in indoor environments. Indoor Air, 30 (4): $557-558$

Andersen B, Frisvad J C, Søndergaard I, Rasmussen I S, Larsen L S (2011). Associations between fungal species and water-damaged building materials. Applied and Environmental Microbiology, 77 (12): 4180-4188

Anderson D J, Chen L F, Weber D J, Moehring R W, Lewis S S, Triplett P F, Blocker M, Becherer P, Schwab J C, Knelson L P, Lokhnygina Y, Rutala W A, Kanamori H, Gergen M F, Sexton D J (2017). Enhanced terminal room disinfection and acquisition and infection caused by multidrug-resistant organisms and Clostridium difficile (the Benefits of Enhanced Terminal Room Disinfection study): a cluster-randomised, multicentre, crossover study. Lancet, 389 (10071): 805-814

Andersson M A, Nikulin M, Köljalg U, Andersson M C, Rainey F, Reijula K, Hintikka E L, Salkinoja-Salonen M (1997). Bacteria, molds, and toxins in water-damaged building materials. Applied and Environmental Microbiology, 63(2): 387-393

Andrews J R, Morrow C, Walensky R P, Wood R (2014). Integrating social contact and environmental data in evaluating tuberculosis transmission in a South African township. Journal of Infectious Diseases, 210(4): 597-603

Arvand M, Jungkind K, Hack A (2011). Contamination of the cold water distribution system of health care facilities by Legionella pneumophila: do we know the true dimension? Eurosurveillance, 16(16): 19844

ASHRAE (2019). ASHRAE Handbook - HVAC Applications.

Ayerst G (1969). The effects of moisture and temperature on growth and spore germination in some fungi. Journal of Stored Products Research, 5(2): 127-141

Barberán A, Dunn R R, Reich B J, Pacifici K, Laber E B, Menninger H L, Morton J M, Henley J B, Leff J W, Miller S L, Fierer N (2015). The ecology of microscopic life in household dust. Proceedings of the Royal Society B: Biological Sciences, 282(1814): 20151139

Bazzoni C B (1914). The Destruction of bacteria through the action of light. American Journal of Public Health, 4(11): 975-992

Beans C (2016). The Microbiome of green design: sustainable building practices may have unforeseen consequences for microbial communities and human health. Bioscience, 66(10): 801-806

Besaratinia A, Yoon J I, Schroeder C, Bradforth S E, Cockburn M, Pfeifer G P (2011). Wavelength dependence of ultraviolet radiation induced DNA damage as determined by laser irradiation suggests that cyclobutane pyrimidine dimers are the principal DNA lesions produced by terrestrial sunlight. FASEB Journal, 25(9): 3079-3091

Bokulich N A, Lewis Z T, Boundy-Mills K, Mills D A (2016). A new perspective on microbial landscapes within food production. Current Opinion in Biotechnology, 37: 182-189

Bonetta S, Bonetta S, Ferretti E, Balocco F, Carraro E (2010). Evaluation of Legionella pneumophila contamination in Italian hotel water systems by quantitative real-time PCR and culture methods. Journal of Applied Microbiology, 108(5): 1576-1583
Borella P, Montagna M T, Romano-Spica V, Stampi S, Stancanelli G, Triassi M, Neglia R, Marchesi I, Fantuzzi G, Tatò D, Napoli C, Quaranta G, Laurenti P, Leoni E, De Luca G, Ossi C, Moro M, D'alcalà G R (2004). Legionella infection risk from domestic hot water. Emerging Infectious Diseases, 10(3): 457-464

Borella P, Montagna M T, Stampi S, Stancanelli G, Romano-Spica V, Triassi M, Marchesi I, Bargellini A, Tatò D, Napoli C, Zanetti F, Leoni E, Moro M, Scaltriti S, Ribera D'alcalà G, Santarpia R, Boccia S (2005). Legionella contamination in hot water of Italian hotels. Applied and Environmental Microbiology, 71(10): 5805-5813

Bragoszewska E, Biedroń I, Kozielska B, Pastuszka J S (2018). Microbiological indoor air quality in an office building in Gliwice, Poland: analysis of the case study. Air Quality, Atmosphere \& Health, 11(6): 729-740

Bramley A M, Dasgupta S, Skarbinski J, Kamimoto L, Fry A M, Finelli L, Jain S (2012). Intensive care unit patients with 2009 pandemic influenza A (H1N1pdm09) virus infection- United States, 2009. Influenza and Other Respiratory Viruses, 6(6): e134-e142

Brickner P W, Vincent R L, First M, Nardell E, Murray M, Kaufman W (2003). The application of ultraviolet germicidal irradiation to control transmission of airborne disease: bioterrorism countermeasure. Public Health Reports, 118(2): 99-114

Brooks B, Olm M R, Firek B A, Baker R, Thomas B C, Morowitz M J, Banfield J F (2017). Strain-resolved analysis of hospital rooms and infants reveals overlap between the human and room microbiome. Nature Communications, 8: 1814

Brown G Z, Kline J, Mhuireach G, Northcutt D, Stenson J (2016). Making microbiology of the built environment relevant to design. Microbiome, 4: 6

Brown-Elliott B A, Wallace R J, Tichindelean C, Sarria J C, Mcnulty S, Vasireddy R, Bridge L, Mayhall C G, Turenne C, Loeffelholz M (2011). Five-year outbreak of community- and hospital-acquired Mycobacterium porcinum infections related to public water supplies. Journal of Clinical Microbiology, 49(12): 4231-4238

Bultman S J (2014). Emerging roles of the microbiome in cancer. Carcinogenesis, 35(2): 249-255

Buse H Y, Lu J, Struewing I T, Ashbolt N J (2014). Preferential colonization and release of Legionella pneumophila from mature drinking water biofilms grown on copper versus unplasticized polyvinylchloride coupons. International Journal of Hygiene and Environmental Health, 217(2-3): 219-225

Carlton E J, Barton K, Shrestha P M, Humphrey J, Newman L S, Adgate J L, Root E, Miller S (2019). Relationships between home ventilation rates and respiratory health in the Colorado Home Energy Efficiency and Respiratory Health (CHEER) study. Environmental Research, 169: 297-307

Chartier Y, Pessoa-Silva C (2009). Natural ventilation for infection control in health-care settings. World Health Organization

Checinska A, Probst A J, Vaishampayan P, White J R, Kumar D, Stepanov V G, Fox G E, Nilsson H R, Pierson D L, Perry J, Venkateswaran K (2015). Microbiomes of the dust particles collected from the International Space Station and Spacecraft Assembly Facilities. Microbiome, 3: 50

Chen Y C, Yu K P, Shao W C, Tseng C H, Pan W C (2018). Novel moldresistant building materials impregnated with thermally reduced nano-silver. Indoor Air, 28(2): 276-286 
Couret D G, Díaz P D R, de la Rosa D F A (2013). Influence of architectural design on indoor environment in apartment buildings in Havana. Renewable Energy, 50: 800-811

Coutinho M L, Miller A Z, Macedo M F (2015). Biological colonization and biodeterioration of architectural ceramic materials: An overview. Journal of Cultural Heritage, 16(5): 759-777

Curtis L T (2008). Prevention of hospital-acquired infections: review of non-pharmacological interventions. Journal of Hospital Infection, 69 (3): 204-219

Cutler N, Viles H (2010). Eukaryotic microorganisms and stone biodeterioration. Geomicrobiology Journal, 27(6-7): 630-646

da Silva G D, Guidelli E J, De Queiroz-Fernandes G M, Chaves M R M, Baffa O, Kinoshita A (2019). Silver nanoparticles in building materials for environment protection against microorganisms. International Journal of Environmental Science and Technology, 16 (3): $1239-1248$

Dade-Robertson M, Keren-Paz A, Zhang M, Kolodkin-Gal I (2017). Architects of nature: growing buildings with bacterial biofilms. Microbial Biotechnology, 10(5): 1157-1163

Dai D, Prussin A J II, Marr L C, Vikesland P J, Edwards M A, Pruden A (2017). Factors shaping the human exposome in the built environment: opportunities for engineering control. Environmental Science \& Technology, 51(14): 7759-7774

Dai T, Vrahas M S, Murray C K, Hamblin M R (2012). Ultraviolet C irradiation: an alternative antimicrobial approach to localized infections? Expert Review of Anti-Infective Therapy, 10(2): 185-195

Dannemiller K C (2019). Moving towards a robust definition for a "healthy" indoor microbiome. mSystems, 4(3): e00074-e19

Dannemiller K C, Gent J F, Leaderer B P, Peccia J (2016). Influence of housing characteristics on bacterial and fungal communities in homes of asthmatic children. Indoor Air, 26(2): 179-192

Dannemiller K C, Weschler C J, Peccia J (2017). Fungal and bacterial growth in floor dust at elevated relative humidity levels. Indoor Air, 27(2): 354-363

Dedesko S, Siegel J A (2015). Moisture parameters and fungal communities associated with gypsum drywall in buildings. Microbiome, 3: 71

Deng Y, Yao J, Wang X, Guo H, Duan D (2012). Transcriptome sequencing and comparative analysis of Saccharina japonica (Laminariales, Phaeophyceae) under blue light induction. PLoS One, 7(6): e39704

Doll S C (2002). Determination of limiting conditions for fungal growth in the built environment: Harvard School of Public Health, Department of Environmental Health

Downing A M W, Blunt T P (1878). III. Researches on the effect of light upon bacteria and other organisms. Proceedings of the Royal Society of London, 26(179-184): 488-500

Dunn R R, Fierer N, Henley J B, Leff J W, Menninger H L (2013). Home life: factors structuring the bacterial diversity found within and between homes. PLoS One, 8(5): e64133

Ege M J, Mayer M, Normand A C, Genuneit J, Cookson W O C M, Braun-Fahrländer C, Heederik D, Piarroux R, Von Mutius E (2011). Exposure to environmental microorganisms and childhood asthma. New England Journal of Medicine, 364(8): 701-709

Fahimipour A K, Hartmann E M, Siemens A, Kline J, Levin D A, Wilson H, Betancourt-Román C M, Brown G Z, Fretz M, Northcutt D,
Siemens K N, Huttenhower C, Green J L, Van Den Wymelenberg K (2018). Daylight exposure modulates bacterial communities associated with household dust. Microbiome, 6: 175

Falkinham J O (2010). Hospital water filters as a source of Mycobacterium avium complex. Journal of Medical Microbiology, 59(10): 1198-1202

Falkinham J O III, Iseman M D, De Haas P, Van Soolingen D (2008). Mycobacterium avium in a shower linked to pulmonary disease. Journal of Water and Health, 6(2): 209-213

Feazel L M, Baumgartner L K, Peterson K L, Frank D N, Harris J K, Pace N R (2009). Opportunistic pathogens enriched in showerhead biofilms. Proceedings of the National Academy of Sciences of the United States of America, 106(38): 16393-16399

Fitzpatrick M C, Bauch C T, Townsend J P, Galvani A P (2019). Modelling microbial infection to address global health challenges. Nature Microbiology, 4(10): 1612-1619

Flores G E, Bates S T, Caporaso J G, Lauber C L, Leff J W, Knight R, Fierer N (2013). Diversity, distribution and sources of bacteria in residential kitchens. Environmental Microbiology, 15(2): 588-596

Flores G E, Bates S T, Knights D, Lauber C L, Stombaugh J, Knight R, Fierer N (2011). Microbial biogeography of public restroom surfaces. PLoS One, 6(11): e28132

Fonseca M J, Tavares F (2011). The Bactericidal effect of sunlight. American Biology Teacher, 73(9): 548-552

Frankel M, Bekö G, Timm M, Gustavsen S, Hansen E W, Madsen A M (2012). Seasonal variations of indoor microbial exposures and their relation to temperature, relative humidity, and air exchange rate. Applied and Environmental Microbiology, 78(23): 8289-8297

Frankel M, Hansen E W, Madsen A M (2014). Effect of relative humidity on the aerosolization and total inflammatory potential of fungal particles from dust-inoculated gypsum boards. Indoor Air, 24 (1): $16-28$

Fujimura K E, Johnson C C, Ownby D R, Cox M J, Brodie E L, Havstad S L, Zoratti E M, Woodcroft K J, Bobbitt K R, Wegienka G, Boushey H A, Lynch S V (2010). Man's best friend? The effect of pet ownership on house dust microbial communities. Journal of Allergy and Clinical Immunology, 126(2): 410-412.e3

Gibbons S M, Schwartz T, Fouquier J, Mitchell M, Sangwan N, Gilbert J A, Kelley S T (2015). Ecological succession and viability of humanassociated microbiota on restroom surfaces. Applied and Environmental Microbiology, 81(2): 765-773

Gilbert J A, Stephens B (2018). Microbiology of the built environment. Nature Reviews. Microbiology, 16(11): 661-670

Goldman R P, Travisano M (2011). Experimental evolution of ultraviolet radiation resistance in Escherichia coli. Evolution; International Journal of Organic Evolution, 65(12): 3486-3498

Grant C, Hunter C A, Flannigan B, Bravery A F (1989). The moisture requirements of moulds isolated from domestic dwellings. International Biodeterioration \& Biodegradation, 25(4): 259-284

Green J L (2014). Can bioinformed design promote healthy indoor ecosystems? Indoor Air, 24(2): 113-115

Guerra F L, Lopes W, Cazarolli J C, Lobato M, Masuero A B, Dal Molin D C C, Bento F M, Schrank A, Vainstein M H (2019). Biodeterioration of mortar coating in historical buildings: microclimatic characterization, material, and fungal community. Building and Environment, 155: 195-209 
Gutarowska B (2010). Metabolic activity of moulds as a factor of building materials biodegradation. Polish Journal of Microbiology, 59(2): 119-124

Hänninen O O (2011). Fundamentals of mold growth in indoor environments and strategies for healthy living: Springer, 277-302

Hartmann B, Benson M, Junger A, Quinzio L, Rohrig R, Fengler B, Farber U W, Wille B, Hempelmann G (2004). Computer keyboard and mouse as a reservoir of pathogens in an intensive care unit. Journal of Clinical Monitoring and Computing, 18(1): 7-12

Hathway E A, Noakes C J, Sleigh P A, Fletcher L A (2011). CFD simulation of airborne pathogen transport due to human activities. Building and Environment, 46(12): 2500-2511

Hegarty B, Dannemiller K C, Peccia J (2018). Gene expression of indoor fungal communities under damp building conditions: implications for human health. Indoor Air, 28(4): 548-558

Hessling M, Spellerberg B, Hoenes K (2017). Photoinactivation of bacteria by endogenous photosensitizers and exposure to visible light of different wavelengths- a review on existing data. FEMS Microbiology Letters, 364(2): fnw270

Heydenreich B, Bellinghausen I, König B, Becker W M, Grabbe S, Petersen A, Saloga J (2012). Gram-positive bacteria on grass pollen exhibit adjuvant activity inducing inflammatory $\mathrm{T}$ cell responses. Clinical and Experimental Allergy, 42(1): 76-84

Hoang C P, Kinney K A, Corsi R L, Szaniszlo P J (2010). Resistance of green building materials to fungal growth. International Biodeterioration \& Biodegradation, 64(2): 104-113

Hobday R A, Dancer S J (2013). Roles of sunlight and natural ventilation for controlling infection: historical and current perspectives. Journal of Hospital Infection, 84(4): 271-282

Hoeksma P, Aarnink A, Ogink N (2015). Effect of temperature and relative humidity on the survival of airborne bacteria. Wageningen: Wageningen UR Livestock Research

Hoisington A J, Brenner L A, Kinney K A, Postolache T T, Lowry C A (2015). The microbiome of the built environment and mental health. Microbiome, 3: 60

Hospodsky D, Qian J, Nazaroff W W, Yamamoto N, Bibby K, RismaniYazdi H, Peccia J (2012). Human occupancy as a source of indoor airborne bacteria. PLoS One, 7(4): e34867

Hospodsky D, Yamamoto N, Nazaroff W W, Miller D, Gorthala S, Peccia J (2015). Characterizing airborne fungal and bacterial concentrations and emission rates in six occupied children's classrooms. Indoor Air, 25(6): 641-652

Hsiao E Y, Mcbride S W, Hsien S, Sharon G, Hyde E R, McCue T, Codelli J A, Chow J, Reisman S E, Petrosino J F, Patterson P H, Mazmanian S K (2013). Microbiota modulate behavioral and physiological abnormalities associated with neurodevelopmental disorders. Cell, 155(7): 1451-1463

Hu J, Ben Maamar S, Glawe A J, Gottel N, Gilbert J A, Hartmann E M (2019). Impacts of indoor surface finishes on bacterial viability. Indoor Air, 29(4): 551-562

Hyvärinen A, Meklin T, Vepsäläinen A, Nevalainen A (2002). Fungi and actinobacteria in moisture-damaged building materials - concentrations and diversity. International Biodeterioration \& Biodegradation, 49(1): 27-37

Hyytiäinen H K, Jayaprakash B, Kirjavainen P V, Saari S E, Holopainen R, Keskinen J, Hämeri K, Hyvärinen A, Boor B E, Täubel M (2018).
Crawling-induced floor dust resuspension affects the microbiota of the infant breathing zone. Microbiome, 6: 25

Jeon Y S, Chun J, Kim B S (2013). Identification of household bacterial community and analysis of species shared with human microbiome. Current Microbiology, 67(5): 557-563

Jump R L P, Pultz M J, Donskey C J (2007). Vegetative Clostridium difficile survives in room air on moist surfaces and in gastric contents with reduced acidity: a potential mechanism to explain the association between proton pump inhibitors and $C$. difficileassociated diarrhea? Antimicrobial Agents and Chemotherapy, 51 (8): 2883-2887

Jurado V, Miller A Z, Cuezva S, Fernandez-Cortes A, Benavente D, Rogerio-Candelera M A, Reyes J, Cañaveras J C, Sanchez-Moral S, Saiz-Jimenez C (2014). Recolonization of mortars by endolithic organisms on the walls of San Roque church in Campeche (Mexico): a case of tertiary bioreceptivity. Construction \& Building Materials, 53: 348-359

Kang K, Ni Y, Li J, Imamovic L, Sarkar C, Kobler M D, Heshiki Y, Zheng T, Kumari S, Wong J C Y, Archna A, Wong C W M, Dingle C, Denizen S, Baker D M, Sommer M O A, Webster C J, Panagiotou G (2018). The environmental exposures and inner-and intercity traffic flows of the metro system may contribute to the skin microbiome and resistome. Cell Reports, 24(5): 1190-1202.e5

Karkman A, Lehtimäki J, Ruokolainen L (2017). The ecology of human microbiota: dynamics and diversity in health and disease. Annals of the New York Academy of Sciences, 1399(1): 78-92

Kembel S W, Jones E, Kline J, Northcutt D, Stenson J, Womack A M, Bohannan B J M, Brown G Z, Green J L (2012). Architectural design influences the diversity and structure of the built environment microbiome. ISME Journal, 6(8): 1469-1479

Kembel S W, Meadow J F, O'connor T K, Mhuireach G, Northcutt D, Kline J, Moriyama M, Brown G Z, Bohannan B J M, Green J L (2014). Architectural design drives the biogeography of indoor bacterial communities. PLoS One, 9(1): e87093

Kettleson E M, Adhikari A, Vesper S, Coombs K, Indugula R, Reponen $\mathrm{T}$ (2015). Key determinants of the fungal and bacterial microbiomes in homes. Environmental Research, 138: 130-135

Kirjavainen P V, Karvonen A M, Adams R I, Täubel M, Roponen M, Tuoresmäki P, Loss G, Jayaprakash B, Depner M, Ege M J, Renz H, Pfefferle P I, Schaub B, Lauener R, Hyvärinen A, Knight R, Heederik D J J, Von Mutius E, Pekkanen J (2019). Farm-like indoor microbiota in non-farm homes protects children from asthma development. Nature Medicine, 25(7): 1089-1095

Klepeis N E, Nelson W C, Ott W R, Robinson J P, Tsang A M, Switzer P, Behar J V, Hern S C, Engelmann W H (2001). The National Human Activity Pattern Survey (NHAPS): a resource for assessing exposure to environmental pollutants. Journal of Exposure Science \& Environmental Epidemiology, 11(3): 231-252

Kline S, Cameron S, Streifel A, Yakrus M A, Kairis F, Peacock K, Besser J, Cooksey R C (2004). An outbreak of bacteremias associated with Mycobacterium mucogenicum in a hospital water supply. Infection Control and Hospital Epidemiology, 25(12): 1042-1049

Kotay S, Chai W, Guilford W, Barry K, Mathers A J (2017). Spread from the sink to the patient: in situ study using green fluorescent protein (GFP)-expressing Escherichia coli to model bacterial dispersion from hand-washing sink-trap reservoirs. Applied and Environmental 
Microbiology, 83(8): e 03327-16

Kovesi T, Zaloum C, Stocco C, Fugler D, Dales R E, Ni A, Barrowman N, Gilbert N L, Miller J D (2009). Heat recovery ventilators prevent respiratory disorders in Inuit children. Indoor Air, 19(6): 489-499

Kundsin R B (1988). Architectural design and indoor microbial pollution. Oxford University Press, USA

Laborel-Préneron A, Ouédraogo K, Simons A, Labat M, Bertron A, Magniont C, Roques C, Roux C, Aubert J E (2018). Laboratory test to assess sensitivity of bio-based earth materials to fungal growth. Building and Environment, 142: 11-21

Lau C S, Chamberlain R S (2016). Probiotics are effective at preventing Clostridium difficile-associated diarrhea: a systematic review and meta-analysis. International Journal of General Medicine, 9: 27-37

Lax S, Cardona C, Zhao D, Winton V J, Goodney G, Gao P, Gottel N, Hartmann E M, Henry C, Thomas P M, Kelley S T, Stephens B, Gilbert J A (2019). Microbial and metabolic succession on common building materials under high humidity conditions. Nature Communications, 10: 1767

Lax S, Smith D P, Hampton-Marcell J, Owens S M, Handley K M, Scott N M, Gibbons S M, Larsen P, Shogan B D, Weiss S, Metcalf J L, Ursell L K, Vazquez-Baeza Y, Van Treuren W, Hasan N A, Gibson M K, Colwell R, Dantas G, Knight R, Gilbert J A (2014). Longitudinal analysis of microbial interaction between humans and the indoor environment. Science, 345(6200): 1048-1052

Lee P C, Su H N (2010). Investigating the structure of regional innovation system research through keyword co-occurrence and social network analysis. Innovation-Management, Policy \& Practice, 12(1): $26-40$

Leung M H Y, Lee P K H (2016). The roles of the outdoors and occupants in contributing to a potential pan-microbiome of the built environment: a review. Microbiome, 4: 21

Leung M H Y, Wilkins D, Li E K T, Kong F K F, Lee P K H (2014). Indoor-air microbiome in an urban subway network: diversity and dynamics. Applied and Environmental Microbiology, 80(21): 67606770

Levin J, Riley L S, Parrish C, English D, Ahn S (2013). The effect of portable pulsed xenon ultraviolet light after terminal cleaning on hospital-associated Clostridium difficile infection in a community hospital. American Journal of Infection Control, 41(8): 746-748

Lindsley W G, Blachere F M, Thewlis R E, Vishnu A, Davis K A, Cao G, Palmer J E, Clark K E, Fisher M A, Khakoo R, Beezhold D H (2010). Measurements of airborne influenza virus in aerosol particles from human coughs. PLoS One, 5(11): e15100

Lins de Sousa D, Araújo Lima R, Zanin I C, Klein M I, Janal M N, Duarte $S$ (2015). Effect of twice-daily blue light treatment on matrixrich biofilm development. PLoS One, 10(7): e0131941

Liu G, Tang C M, Exley R M (2015). Non-pathogenic Neisseria: members of an abundant, multi-habitat, diverse genus. MicrobiologySGM, 161(7): 1297-1312

Lloyd-Price J, Abu-Ali G, Huttenhower C (2016). The healthy human microbiome. Genome Medicine, 8: 51

Lopez G U, Gerba C P, Tamimi A H, Kitajima M, Maxwell S L, Rose J B (2013). Transfer efficiency of bacteria and viruses from porous and nonporous fomites to fingers under different relative humidity conditions. Applied and Environmental Microbiology, 79(18): $5728-5734$
Lowry C A, Smith D G, Siebler P H, Schmidt D, Stamper C E, Hassell J E Jr, Yamashita P S, Fox J H, Reber S O, Brenner L A, Hoisington A $\mathrm{J}$, Postolache T T, Kinney K A, Marciani D, Hernandez M, Hemmings S M J, Malan-Muller S, Wright K P, Knight R, Raison C L, Rook G A W (2016). The Microbiota, immunoregulation, and mental Health: Implications for public health. Current Environmental Health Reports, 3(3): 270-286

Lugauskas A, Levinskaite L, Peciulyte D (2003). Micromycetes as deterioration agents of polymeric materials. International Biodeterioration \& Biodegradation, 52(4): 233-242

Luongo J C, Barberan A, Hacker-Cary R, Morgan E E, Miller S L, Fierer N (2017). Microbial analyses of airborne dust collected from dormitory rooms predict the sex of occupants. Indoor Air, 27(2): 338-344

Maclean M, Anderson J G, Macgregor S J, White T, Atreya C D (2016). A new proof of concept in bacterial reduction: antimicrobial action of violet-blue light $(405 \mathrm{~nm})$ in ex vivo stored plasma. Journal of Blood Transfusion, 2016: 1-11

Madhav N, Oppenheim B, Gallivan M, Mulembakani P, Rubin E, Wolfe N (2017). Pandemics: Risks, Impacts, and Mitigation: The World Bank, 315-345

Mahnert A, Moissl-Eichinger C, Berg G (2015). Microbiome interplay: plants alter microbial abundance and diversity within the built environment. Frontiers in Microbiology, 6: 887

Marchesi I, Marchegiano P, Bargellini A, Cencetti S, Frezza G, Miselli M, Borella P (2011). Effectiveness of different methods to control legionella in the water supply: ten-year experience in an Italian university hospital. Journal of Hospital Infection, 77(1): 47-51

Mathys W, Stanke J, Harmuth M, Junge-Mathys E (2008). Occurrence of Legionella in hot water systems of single-family residences in suburbs of two German cities with special reference to solar and district heating. International Journal of Hygiene and Environmental Health, 211(1-2): 179-185

Meadow J F, Altrichter A E, Bateman A C, Stenson J, Brown G Z, Green J L, Bohannan B J M (2015). Humans differ in their personal microbial cloud. PeerJ, 3: e1258

Meadow J F, Altrichter A E, Kembel S W, Kline J, Mhuireach G, Moriyama M, Northcutt D, O'connor T K, Womack A M, Brown G Z, Green J L, Bohannan B J M (2014a). Indoor airborne bacterial communities are influenced by ventilation, occupancy, and outdoor air source. Indoor Air, 24(1): 41-48

Meadow J F, Altrichter A E, Kembel S W, Moriyama M, O'connor T K, Womack A M, Brown G Z, Green J L, Bohannan B J M (2014b). Bacterial communities on classroom surfaces vary with human contact. Microbiome, 2: 7

Medeiros A B A, Enders B C, Lira A L B C (2015). The Florence Nightingale's environmental theory: a critical analysis. Escola Anna Nery, 19(3): 518-524

Memarzadeh F (2013). Literature review: room ventilation and airborne disease transmission. American Society for Healthcare Engineering

Menzies D, Popa J, Hanley J A, Rand T, Milton D K (2003). Effect of ultraviolet germicidal lights installed in office ventilation systems on workers' health and wellbeing: double-blind multiple crossover trial. Lancet, 362(9398): 1785-1791

Miletto M, Lindow S E (2015). Relative and contextual contribution of different sources to the composition and abundance of indoor air 
bacteria in residences. Microbiome, 3: 61

Miller R, Simmons S, Dale C, Stachowiak J, Stibich M (2015). Utilization and impact of a pulsed-xenon ultraviolet room disinfection system and multidisciplinary care team on Clostridium difficile in a long-term acute care facility. American Journal of Infection Control, 43(12): 1350-1353

Mouchtouri V, Velonakis E, Tsakalof A, Kapoula C, Goutziana G, Vatopoulos A, Kremastinou J, Hadjichristodoulou C (2007). Risk factors for contamination of hotel water distribution systems by Legionella species. Applied and Environmental Microbiology, 73(5): 1489-1492

Mudarri D, Fisk W J (2007). Public health and economic impact of dampness and mold. Indoor Air, 17(3): 226-235

Mukherjee N, Dowd S, Wise A, Kedia S, Vohra V, Banerjee P (2014). Diversity of bacterial communities of fitness center surfaces in a U.S. metropolitan area. International Journal of Environmental Research and Public Health, 11(12): 12544-12561

Nagaraja A, Visintainer P, Haas J P, Menz J, Wormser G P, Montecalvo M A (2015). Clostridium difficile infections before and during use of ultraviolet disinfection. American Journal of Infection Control, 43(9): 940-945

NASEM (2017). Microbiomes of the built environment: a research agenda for indoor microbiology, human health, and buildings: National Academies Press

Nazaroff W W, Weschler C J (2004). Cleaning products and air fresheners: exposure to primary and secondary air pollutants. Atmospheric Environment, 38(18): 2841-2865

Nice J A, Bole S (2016). Investigating the impact of architectural planning and functional program on the indoor microbiome. A health concern. In: Proceeding of the 14th International Conference of Indoor Air Quality and Climate Ghent, Belgium

Nightingale F (1863). Notes on hospitals. Longman, Green, Longman, Roberts, and Green

Nordahl Petersen T, Rasmussen S, Hasman H, Carøe C, Bælum J, Charlotte Schultz A, Bergmark L, Svendsen C A, Lund O, SicheritzPontén T, Aarestrup F M (2015). Meta-genomic analysis of toilet waste from long distance flights; a step towards global surveillance of infectious diseases and antimicrobial resistance. Scientific Reports, 5: 11444

NRC (2006). Drinking Water Distribution Systems: Assessing and Reducing Risks. National Academies Press

Ondrusch N, Kreft J (2011). Blue and red light modulates SigBdependent gene transcription, swimming motility and invasiveness in Listeria monocytogenes. PLoS One, 6(1): e16151

Oppezzo O J (2012). Contribution of UVB radiation to bacterial inactivation by natural sunlight. Journal of Photochemistry and Photobiology. B, Biology, 115: 58-62

Pasanen A L, Juutinen T, Jantunen M J, Kalliokoski P (1992). Occurrence and moisture requirements of microbial growth in building materials. International Biodeterioration \& Biodegradation, 30(4): 273-283

Paszko-Kolva C, Sawyer T K, Palmer C J, Nerad T A, Fayer R (1998). Examination of microbial contaminants of emergency showers and eyewash stations. Journal of Industrial Microbiology \& Biotechnology, 20(3-4): 139-143

Patra V, Byrne S N, Wolf P (2016). The skin microbiome: Is it affected by UV-induced immune suppression? Frontiers in Microbiology, 7: 1235

Perkins S D, Mayfield J, Fraser V, Angenent L T (2009). Potentially pathogenic bacteria in shower water and air of a stem cell transplant unit. Applied and Environmental Microbiology, 75(16): 5363-5372

Pessi A-M, Suonketo J, Pentti M, Kurkilahti M, Peltola K, RantioLehtimaki, A (2002). Microbial growth inside insulated external walls as an indoor air biocontamination source. Applied and Environmental Microbiology, 68(2): 963-967

Ponsoni K, Raddi M S G (2010). Indoor air quality related to occupancy at an air-conditioned public building. Brazilian Archives of Biology and Technology, 53(1): 99-103

Popkin B M (1999). Urbanization, lifestyle changes and the nutrition transition. World Development, 27(11): 1905-1916

Prather K A, Wang C C, Schooley R T (2020). Reducing transmission of SARS-CoV-2. Science, 368(6498): 1422-1424

Prescott S L, Larcombe D L, Logan A C, West C, Burks W, Caraballo L, Levin M, Etten E V, Horwitz P, Kozyrskyj A, Campbell D E (2017). The skin microbiome: impact of modern environments on skin ecology, barrier integrity, and systemic immune programming. World Allergy Organization Journal, 10: 29

Proctor C R, Dai D, Edwards M A, Pruden A (2017). Interactive effects of temperature, organic carbon, and pipe material on microbiota composition and Legionella pneumophila in hot water plumbing systems. Microbiome, 5: 130

Prussin A J II, Schwake D O, Marr L C (2017). Ten questions concerning the aerosolization and transmission of Legionella in the built environment. Building and Environment, 123: 684-695

Purcell A T (1987). The relationship between buildings and behaviour. Building and Environment, 22(3): 215-232

Putri W C W S, Muscatello D J, Stockwell M S, Newall A T (2018). Economic burden of seasonal influenza in the United States. Vaccine, 36(27): 3960-3966

Qian J, Hospodsky D, Yamamoto N, Nazaroff W W, Peccia J (2012). Size-resolved emission rates of airborne bacteria and fungi in an occupied classroom. Indoor Air, 22(4): 339-351

Ridaura V K, Faith J J, Rey F E, Cheng J, Duncan A E, Kau A L, Griffin N W, Lombard V, Henrissat B, Bain J R, Muehlbauer M J, Ilkayeva O, Semenkovich C F, Funai K, Hayashi D K, Lyle B J, Martini M C, Ursell L K, Clemente J C, Van Treuren W, Walters W A, Knight R, Newgard C B, Heath A C, Gordon J I (2013). Gut microbiota from twins discordant for obesity modulate metabolism in mice. Science, 341(6150): 1241214

Rintala H, Nevalainen A, Suutari M (2002). Diversity of streptomycetes in water-damaged building materials based on $16 \mathrm{~S}$ rDNA sequences. Letters in Applied Microbiology, 34(6): 439-443

Riva M A, Benedetti M, Cesana G (2014). Pandemic fear and literature: Observations from Jack London's The Scarlet Plague. Emerging Infectious Diseases, 20(10): 1753-1757

Rivera J M, Aguilar L, Granizo J J, Vos-Arenilla A, Giménez M J, Aguiar J M, Prieto J (2007). Isolation of Legionella species/ serogroups from water cooling systems compared with potable water systems in Spanish healthcare facilities. Journal of Hospital Infection, 67(4): 360-366

Robertson C E, Baumgartner L K, Harris J K, Peterson K L, Stevens M J, Frank D N, Pace N R (2013). Culture-independent analysis of aerosol 
microbiology in a metropolitan subway system. Applied and Environmental Microbiology, 79(11): 3485-3493

Ross A A, Doxey A C, Neufeld J D (2017). The skin microbiome of cohabiting couples. mSystems, 2(4): e00043-17

Ross A A, Neufeld J D (2015). Microbial biogeography of a university campus. Microbiome, 3: 66

Round J L, Mazmanian S K (2009). The gut microbiota shapes intestinal immune responses during health and disease. Nature Reviews. Immunology, 9(5): 313-323

Salathe M, Kazandjieva M, Lee J W, Levis P, Feldman M W, Jones J H (2010). A high-resolution human contact network for infectious disease transmission. Proceedings of the National Academy of Sciences of the United States of America, 107(51): 22020-22025

Sandhu B S, Singh C K (2009). Relationship of sunlight and humidity on the virulence of street rabies virus in saliva. Indian Journal of Animal Sciences, 79: 24

Seppanen O, Fisk W J (2002). Relationship of SBS-symptoms and ventilation system type in office buildings. In: Proceedings of 9th International Conference on Indoor Air Quality and Climate, Monterey, California

Sheffer P J, Stout J E, Wagener M M, Muder R R (2005). Efficacy of new point-of-use water filter for preventing exposure to Legionella and waterborne bacteria. American Journal of Infection Control, 33(5): S20-S25

Simons A, Bertron A, Roux C, Laborel-Préneron A, Aubert J E, Roques C (2019). Susceptibility of earth-based construction materials to fungal proliferation: laboratory and in situ assessment. RILEM Technical Letters, 3: 140-149

Sliney D (2013). Balancing the risk of eye irritation from UV-C with infection from bioaerosols. Photochemistry and Photobiology, 89(4): 770-776

Smith D P, Alverdy J C, Siegel J A (2013). Design considerations for home and hospital microbiome studies: National Academies Press

Stefanowski B K, Curling S F, Ormondroyd G A (2017). A rapid screening method to determine the susceptibility of bio-based construction and insulation products to mould growth. International Biodeterioration \& Biodegradation, 116: 124-132

Sydnor E R M, Bova G, Gimburg A, Cosgrove S E, Perl T M, Maragakis L L (2012). Electronic-eye faucets: Legionella species contamination in healthcare settings. Infection Control and Hospital Epidemiology, 33(3): 235-240

Takada A, Matsushita K, Horioka S, Furuichi Y, Sumi Y (2017). Bactericidal effects of $310 \mathrm{~nm}$ ultraviolet light-emitting diode irradiation on oral bacteria. BMC Oral Health, 17: 96

Tang J W (2009). The effect of environmental parameters on the survival of airborne infectious agents. Journal of the Royal Society, Interface, 6(suppl_6): S737-S746

Täubel M, Leppänen H K (2017). Microbial Exposures in Schools and Daycare Centers: in Exposure to Microbiological Agents in Indoor and Occupational Environments Springer International Publishing, 253-287

Thomas V, Herrera-Rimann K, Blanc D S, Greub G (2006). Biodiversity of amoebae and amoeba-resisting bacteria in a hospital water network. Applied and Environmental Microbiology, 72(4): 24282438

Thomson R, Tolson C, Carter R, Coulter C, Huygens F, Hargreaves M
(2013). Isolation of nontuberculous mycobacteria (NTM) from household water and shower aerosols in patients with pulmonary disease caused by NTM. Journal of Clinical Microbiology, 51(9): 3006-3011

Tringe S G, Zhang T, Liu X, Yu Y, Lee W H, Yap J, Yao F, Suan S T, Ing S K, Haynes M, Rohwer F, Wei C L, Tan P, Bristow J, Rubin E M, Ruan Y (2008). The airborne metagenome in an indoor urban environment. PLoS One, 3(4): e1862

Tsongas G A, Riordan F (2016). Minimum conditions for visible mold growth. ASHRAE Journal, 58(9): 32

Tuomi T, Reijula K, Johnsson T, Hemminki K, Hintikka E L, Lindroos O, Kalso S, Koukila-Kähkälä P, Mussalo-Rauhamaa H, Haahtela T (2000). Mycotoxins in crude building materials from water-damaged buildings. Applied and Environmental Microbiology, 66(5): 18991904

Turnbaugh P J, Ley R E, Mahowald M A, Magrini V, Mardis E R, Gordon J I (2006). An obesity-associated gut microbiome with increased capacity for energy harvest. Nature, 444(7122): 10271031

Udawattha C, Galkanda H, Ariyarathne I S, Jayasinghe G Y, Halwatura R (2018). Mold growth and moss growth on tropical walls. Building and Environment, 137: 268-279

Vacher S, Hernandez C, Bärtschi C, Poussereau N (2010). Impact of paint and wall-paper on mould growth on plasterboards and aluminum. Building and Environment, 45(4): 916-921

van der Kooij D, Veenendaal H R, Scheffer W J (2005). Biofilm formation and multiplication of Legionella in a model warm water system with pipes of copper, stainless steel and cross-linked polyethylene. Water Research, 39(13): 2789-2798

van Eck N J, Waltman L (2010). Software survey: VOSviewer, a computer program for bibliometric mapping. Scientometrics, 84(2): 523-538

Verdier T, Coutand M, Bertron A, Roques C (2014). A review of indoor microbial growth across building materials and sampling and analysis methods. Building and Environment, 80: 136-149

Wang H, Edwards M, Falkinham J O III, Pruden A (2012). Molecular survey of the occurrence of Legionella spp., Mycobacterium spp., Pseudomonas aeruginosa, and amoeba hosts in two chloraminated drinking water distribution systems. Applied and Environmental Microbiology, 78(17): 6285-6294

Warscheid T, Braams J (2000). Biodeterioration of stone: a review. International Biodeterioration \& Biodegradation, 46(4): 343-368

Weber D J, Kanamori H, Rutala W A (2016). 'No touch' technologies for environmental decontamination. Current Opinion in Infectious Diseases, 29(4): 424-431

West R, Michie S, Rubin G J, Amlôt R (2020). Applying principles of behaviour change to reduce SARS-CoV-2 transmission. Nature Human Behaviour, 4(5): 451-459

Wilkins D, Leung M H Y, Lee P K H (2016). Indoor air bacterial communities in Hong Kong households assemble independently of occupant skin microbiomes. Environmental Microbiology, 18(6): 1754-1763

Williams M M, Chen T H, Keane T, Toney N, Toney S, Armbruster C R, Butler W R, Arduino M J (2011). Point-of-use membrane filtration and hyperchlorination to prevent patient exposure to rapidly growing mycobacteria in the potable water supply of a skilled nursing facility. 
Infection Control and Hospital Epidemiology, 32(9): 837-844

Wolkoff P (2018). Indoor air humidity, air quality, and health - An overview. International Journal of Hygiene and Environmental Health, 221(3): 376-390

Wood M, Gibbons S M, Lax S, Eshoo-Anton T W, Owens S M, Kennedy S, Gilbert J A, Hampton-Marcell J T (2015). Athletic equipment microbiota are shaped by interactions with human skin. Microbiome, 3: 25

Wood R, Morrow C, Ginsberg S, Piccoli E, Kalil D, Sassi A, Walensky R P, Andrews J R (2014). Quantification of shared air: A social and environmental determinant of airborne disease transmission. PLoS One, 9(9): e106622

Wu T, Taubel M, Holopainen R, Viitanen A K, Vainiotalo S, Tuomi T, Keskinen J, Hyvarinen A, Hameri K, Saari S E, Boor B E (2018). Infant and adult inhalation exposure to resuspended biological particulate matter. Environmental Science \& Technology, 52(1): 237-247

Yamamoto N, Hospodsky D, Dannemiller K C, Nazaroff W W, Peccia J (2015). Indoor emissions as a primary source of airborne allergenic fungal particles in classrooms. Environmental Science \& Technology, 49(8): 5098-5106
Yapicioglu H, Gokmen T G, Yildizdas D, Koksal F, Ozlu F, KaleCekinmez E, Mert K, Mutlu B, Satar M, Narli N, Candevir A (2012). Pseudomonas aeruginosa infections due to electronic faucets in a neonatal intensive care unit. Journal of Paediatrics and Child Health, 48(5): 430-434

You R, Cui W, Chen C, Zhao B (2013). Measuring the short-term emission rates of particles in the "personal cloud" with different clothes and activity intensities in a sealed chamber. Aerosol and Air Quality Research, 13(3): 911-921

Yu V L, Stout J E (2000). Hospital characteristics associated with colonization of water systems by Legionella and risk of nosocomial Legionnaires' disease: A cohort study of 15 hospitals. Infection Control and Hospital Epidemiology, 21(7): 434-435

Zhao Y, Aarnink A J A, Dijkman R, Fabri T, De Jong M C M, Groot Koerkamp P W G (2012). Effects of temperature, relative humidity, absolute humidity, and evaporation potential on survival of airborne Gumboro vaccine virus. Applied and Environmental Microbiology, 78(4): 1048-1054

Zifferblatt S M (1972). Architecture and human behavior: Toward increased understanding of a functional relationship. Educational Technology, 12(8): 54-57 